\title{
RES Usage in the Context of Sustainable Energy Development: Countries of the Eurasian Economic Union
}

\author{
Tatsiana Zoryna $^{1 *}$, Yauheniya Shershunovich ${ }^{1}$ \\ ${ }^{1}$ Institute of Power Engineering of the Academy of Sciences of Belarus, Akademicheskaya Str. 15/2, Minsk, Belarus
}

\begin{abstract}
The authors have made a hypothesis that there are groups of the countries with a similar level of certain factors development (the level of economic development; the amount of harmful emissions in the atmosphere; the electrification level; the stock level of energy resources) for which application of a certain set of strategies within the concept of sustainable energy development is the most typical. To implement this hypothesis in this article the cluster analysis was carried out to allocate groups of the countries with the similar characteristics. The vertically integrated hierarchical structure of strategies was constructed. And the most typical strategies of sustainable energy development for 149 countries were revealed. By means of the discriminant analysis the most characteristic strategies of sustainable energy development for each cluster were defined. According to the research, for the EEU countries the most typical strategy in the power industry is use of RES. The analysis of renewable energy development in the EEU countries in 2000-2015 was carried out and the barriers and prospects of its further application in these countries were revealed.
\end{abstract}

\section{Introduction}

The The recent world trends in primary energy consumption include:

- The gradual transition in the fuel mix is set to continue with renewables, together with nuclear power, expected to account for half of the growth in energy supplies over the next 20 years.

- Even so, oil, gas and coal remain the dominant sources of energy powering the world economy accounting for more than three-quarters of total energy supplies in 2035 (down from 85\% in 2015).

- Out of these, gas is the fastest growing fuel (1.6\% p.a.), with its share in primary energy increasing as it overtakes coal to be the second-largest fuel source by 2035.

- Oil continues to grow ( $0.7 \%$ p.a.), although its pace of growth is expected to slow gradually.

- The growth of coal is projected to decline sharply: $0.2 \%$ p.a. compared with $2.7 \%$ p.a. over the past 20 years - coal consumption is expected to peak in the mid2020s.

- Renewable energy is the fastest growing source of energy $(7.1 \%$ p.a.), with its share in primary energy increasing to $10 \%$ by 2035, up from 3\% in 2015.

Growing prices for fossil fuels, depletion of natural resources, problems with meeting the increasing demand for electricity, carbon dioxide emissions as a result of burning fossil fuels contribute to the fact that the energy policy in different countries undergoes serious changes. If in the European Union the Renewable energy directive sets a binding target of $20 \%$ final energy consumption from renewable sources by 2020, the situation in the Eurasian Economic Union is quite different.

\section{Methods}

Main The number of factors which predetermine the possibility of this or that strategy use within the concept of sustainable energy development include: 1) the level of economic development (the indicator - GDP per capita in thousands of US dollars); 2) the amount of harmful emissions in the atmosphere (the indicator CO2 emissions in metric tons per capita); 3) the electrification level (the indicator - access to electricity in $\%$ of population); 4) the stock level of energy resources (the indicator - \% of domestic primary energy usage (coal, natural gas and oil) for electricity production).

At the first stage of the research to analyze the specified above indicators data on 149 countries for 2010 was collected. The official sites of the World Bank [1], energy statistics of the UN Department of Economic and Social Affairs [2], the IEA energy statistics of OECD countries [3] were the sources.

To define the groups of the countries with a similar development level of the specified factors the method of the hierarchical cluster analysis was used. The square of Euclidean distance was chosen as a measure of similarity. The square of Euclidean distance represents the sum of squares of differences in values for each variable. It is the most often used measure of similarity. On the basis of the agglomeration steps analysis it was defined that 12 clusters are optimum for the 
classification of these set of countries [4]. For division of the countries into clusters the software package of SPSS was used.

To simplify the interpretation of the results quantitative characteristics of the factors used in the analysis were divided into 3 categories characterizing low, average and high value. The interval for each row was defined on the basis of the range of variation. The upper bound of the "low" category was calculated taking into account the minimum value of the indicator and the interval. The upper bound of the "medium" category was defined on the basis of the interval and the value of the upper bound of the "low" category.

Table 1. Classification criteria in terms of 3 categories division

\begin{tabular}{|c|c|c|c|c|}
\hline $\begin{array}{l}\text { Cate- } \\
\text { gory }\end{array}$ & $\begin{array}{l}\text { The level of } \\
\text { economic } \\
\text { develop- } \\
\text { ment (GDP } \\
\text { per capita in } \\
\text { thousands of } \\
\text { US dollars) }\end{array}$ & $\begin{array}{l}\text { The } \\
\text { amount of } \\
\text { harmful } \\
\text { emissions } \\
\text { in the } \\
\text { atmo- } \\
\text { sphere } \\
\left(\mathrm{CO}_{2}\right. \\
\text { emissions } \\
\text { in metric } \\
\text { tons per } \\
\text { capita) }\end{array}$ & $\begin{array}{l}\text { The } \\
\text { electrificati } \\
\text { on level } \\
\text { (access to } \\
\text { electricity } \\
\text { in \% of } \\
\text { population) }\end{array}$ & $\begin{array}{l}\text { The stock } \\
\text { level of } \\
\text { energy } \\
\text { resources } \\
\text { (\% of } \\
\text { domestic } \\
\text { primary } \\
\text { energy } \\
\text { usage } \\
\text { (coal, } \\
\text { natural } \\
\text { gas and } \\
\text { oil) for } \\
\text { electricity } \\
\text { produ- } \\
\text { ction) }\end{array}$ \\
\hline Low & $\begin{array}{ll}\text { Less } & \text { than } \\
34.003 & \end{array}$ & $\begin{array}{l}\text { Less } \\
\text { than13.45 } \\
7\end{array}$ & $\begin{array}{l}\text { Less than } \\
39\end{array}$ & $\begin{array}{l}\text { Less than } \\
33.33\end{array}$ \\
\hline $\begin{array}{l}\text { Me- } \\
\text { dium }\end{array}$ & $\begin{array}{l}34.003- \\
68.007 \\
\end{array}$ & $\begin{array}{l}13.457- \\
26.883 \\
\end{array}$ & 39-69.5 & $\begin{array}{l}33.33- \\
66.67 \\
\end{array}$ \\
\hline High & $\begin{array}{l}\text { More than } \\
68.007\end{array}$ & $\begin{array}{l}\text { More than } \\
26.883\end{array}$ & $\begin{array}{l}\text { More than } \\
69.5\end{array}$ & $\begin{array}{l}\text { More } \\
\text { than } \\
66.67\end{array}$ \\
\hline
\end{tabular}

The second stage of the research included the analysis of legal acts and program documents in energy policy of the countries till 2020 in order to define the strategies of sustainable energy development. Therefore the most typical strategies within the realization of a sustainable development policy of the countries were pointed out. They include:

1) electrification;

2) energy saving;

3) expansion and modernization of energy sources;

4) use of local fossil resources;

5) use of energy efficiency technologies;

6) decrease in the emissions of $\mathrm{CO} 2$;

7) use of RES (renewable energy sources);

8) energy security;

9) use of nuclear power;

10) energy industry restructuring;

11) diversification of resources and energy sources.

For this purpose we constructed the database containing strategies of the countries in a section of clusters. It allowed us to define the most typical strategies.

Then at the third stage of the research we used the method of a circle of problems analysis to create the hierarchical structure of the strategies presented in figure 1 in the section "results". The method of a circle of problems analysis was used to create the hierarchical structure of the strategies. This method consists in establishment of the interrelation "reason- consequence". All the strategies are interconnected among themselves. To check the hypothesis of existence of typical strategies for each cluster we used the multiple discriminant analysis. Membership of the country in the cluster was the dependent variable and the predictors were the strategies. If clusters and discriminant groups coincide, it means there is a relation between the characteristics of the countries and the strategies used by them. The implementation of the discriminant analysis was carried out by the means of a software package SPSS. The classification includes 12 groups.

The fourth stage of the research was focused on the countries of the Eurasian Economic Union and included data collection and analysis on the electricity production for Armenia, Belarus, Kazakhstan, Kyrgyz Republic, Russia for the period 2000-2015. The data is with a breakdown into different energy resources. The official site of the International Energy agency and sites of the Ministries of Energy and Ministries of Statistics of the Eurasian Economic Union countries were the sources for the data. At this stage the comparative analysis of the strategies recommended for the countries of the Eurasian Economic Union was made, with a particular focus on the RES usage strategy.

\section{Results}

\section{A. Segmentation of the countries at the basis of the cluster analysis}

The method of segmentation on the basis of the cluster analysis has been applied to allocation of the countries with the similar characteristics by the criteria listed in the table 1.

Table 2 reflects the results of the cluster analysis of the countries together with their classification criteria.

Table 3 presents the countries in each cluster. 
Table 2. Clusters description

\begin{tabular}{|c|c|c|c|c|}
\hline \multirow[b]{2}{*}{ 离 } & \multicolumn{4}{|c|}{ Description } \\
\hline & 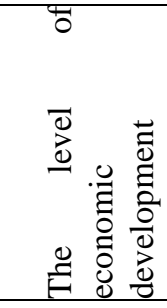 & 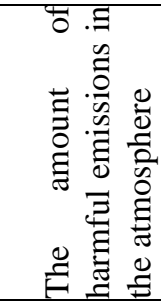 & 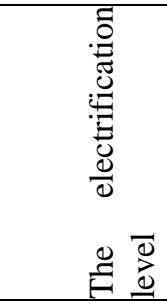 & 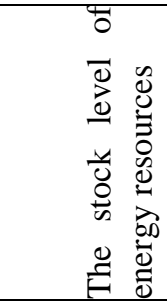 \\
\hline 1 & low & low & medium & $\begin{array}{l}\text { low or } \\
\text { medium }\end{array}$ \\
\hline 2 & low & low & low & $\begin{array}{l}\text { low or } \\
\text { medium }\end{array}$ \\
\hline 3 & $\begin{array}{l}\text { low or } \\
\text { medium }\end{array}$ & low & high & low \\
\hline 4 & low & low & $\begin{array}{l}\text { high or } \\
\text { medium }\end{array}$ & high \\
\hline 5 & $\begin{array}{l}\text { low or } \\
\text { medium }\end{array}$ & low & high & medium \\
\hline 6 & medium & medium & high & high \\
\hline 7 & low & medium & high & $\begin{array}{l}\text { high or } \\
\text { medium }\end{array}$ \\
\hline 8 & high & $\begin{array}{l}\text { low or } \\
\text { medium }\end{array}$ & high & low \\
\hline 9 & low & low & low & high \\
\hline 10 & $\begin{array}{l}\text { low or } \\
\text { medium }\end{array}$ & high & high & high \\
\hline 11 & $\begin{array}{l}\text { high or } \\
\text { medium }\end{array}$ & low & high & high \\
\hline 12 & high & high & high & high \\
\hline
\end{tabular}

Table 3. Countries in the clusters

\begin{tabular}{|l|l|}
\hline & \multicolumn{1}{|c|}{ Countries } \\
\hline 1 & $\begin{array}{l}\text { Angola, Cameroon, Gabon, Ghana, Namibia, } \\
\text { Pakistan, Senegal, Yemen }\end{array}$ \\
\hline 2 & $\begin{array}{l}\text { Afghanistan, Benin, Burkina Faso, Cambodia, } \\
\text { Eritrea, Ethiopia, Haiti, Kenya, Madagascar, } \\
\text { Malawi, Sudan, Togo, Uganda, Zambia }\end{array}$ \\
\hline Albania, Armenia, Austria, Barbados, Belarus, \\
Belgium, Bhutan, Brazil, Burundi, Costa Rica, \\
Croatia, Cuba, Cyprus, Dominica, Dominican \\
Republic, Ecuador, El Salvador, Finland, France, \\
Gambia, Georgia, Grenada, Guatemala, Guyana, \\
Honduras, Hong Kong, Iceland, Ireland, Italy, \\
Jamaica, Japan, Jordan, the Republic of Korea, \\
Kyrgyz Republic, Latvia, Lebanon, Lithuania, \\
Malta, Mauritania, Mauritius, Moldova, Morocco, \\
Nepal, Nicaragua, Papua New Guinea, Paraguay, \\
Portugal, Singapore, Slovak Republic, Spain, Sri \\
Lanka, Suriname, Sweden, Tajikistan, Turkey, \\
Uruguay
\end{tabular}

\begin{tabular}{|l|l|}
\hline & $\begin{array}{l}\text { Algeria, Argentina, Azerbaijan, Bangladesh, } \\
\text { Bolivia, Bosnia and Herzegovina, Botswana, Chile, } \\
\text { China, Colombia, Cote d'Ivoire, Czech Republic, } \\
\text { Egypt, Greece, India, Indonesia, Iran, Macedonia, } \\
\text { Mexico, Mongolia, Montenegro, Myanmar, New } \\
\text { Zealand, Niger, Nigeria, Peru, Poland, Romania, } \\
\text { Russia, Serbia, South Africa, Turkmenistan, } \\
\text { Ukraine, Uzbekistan, Vietnam }\end{array}$ \\
\hline & $\begin{array}{l}\text { Bulgaria, Germany, Hungary, Iraq, Israel, } \\
\text { Malaysia, Philippines, Slovenia, Syrian Arab } \\
5\end{array}$ \\
\hline 6 & $\begin{array}{l}\text { Republic, Thailand, Tunisia, United Kingdom, } \\
\text { Australia, Canada, USA, UAE }\end{array}$ \\
\hline 7 & $\begin{array}{l}\text { Bahrain, Brunei Darussalam, Estonia, Kazakhstan, } \\
\text { Oman, Saudi Arabia }\end{array}$ \\
\hline 8 & Luxembourg, Switzerland \\
\hline 9 & $\begin{array}{l}\text { The Republic of Congo, the Democratic Republic } \\
\text { of Congo, Mozambique, Tanzania, Zimbabwe }\end{array}$ \\
\hline 10 & Kuwait, Trinidad and Tobago \\
\hline 11 & Denmark, Netherlands, Norway \\
\hline 12 & Qatar \\
\hline
\end{tabular}

\section{B. Classification of the sustainable energy development strategies}

The hierarchical structure of strategies created with the method of a circle of problems analysis, is presented in figure 1. Apparently from the figure 1, all the strategies are interconnected among themselves. Use of RES, use of nuclear power, use of local fossil resources, energy industry restructuring belong to the strategies of the zero level. They can be used for realization of strategies of higher levels and have one exit. The strategies of the zero level directly participate in realization of the strategies of the first level. Also they indirectly participate in realization of the strategies of the second level. Many countries realize the strategy of diversification of resources and energy sources at the expense of RES and nuclear power. The use of RES, being the strategy of the zero level, promotes electrification of the countries not directly, but through the expansion and modernization of energy sources. While introducing RES in the energy balance to increase the level of electrification the country expands the number of used energy sources. However, it is necessary to point out, that not all the countries define the strategies of the first level in the program documents on energy policy and often realization of the strategies of the second level due to the use of strategies of the zero level goes without indication of the strategies of the first level.

Use of power effective technologies, diversification of resources and energy sources, expansion and modernization of energy sources belong to the strategies of the first level. They have the strategies of the zero level as an entrance, and as a way out - the strategies of the second level. Thus, the strategy of the first level can be a link between the strategies of the zero and the second levels. 
Electrification, decrease in the emissions of $\mathrm{CO}_{2}$, energy security, energy saving belong to the strategies of the second level. The strategies of this level have one entrance from the strategy of the first level. For example, the strategy of energy saving is often realized by introduction of energy efficiency technologies. The strategy of energy saving is the most self-sufficient in comparison with all the other strategies as it has the entrance only from one strategy of the first level (use of energy efficiency technologies).

When forming their energy policy various countries define the strategies relating to various levels in different ways. Some countries list strategy of all the three levels when forming the energy policy including strategic objectives and ways of their achievement. For example, Kazakhstan plans use of RES, use of local fossil resources, use of nuclear power (the strategies of the zero level), use of energy efficiency technologies, expansion and modernization of energy sources (the strategies of the first level), decrease in the emissions of $\mathrm{CO}_{2}$, energy saving (the strategies of the second level). Part of the countries is guided by the tactical tasks for a certain term promoting realization of the strategies of the zero and the first levels.

Due to various approaches of the countries to formulation of the strategies of sustainable energy development in the further analysis the decision was made to use all the strategies listed earlier.

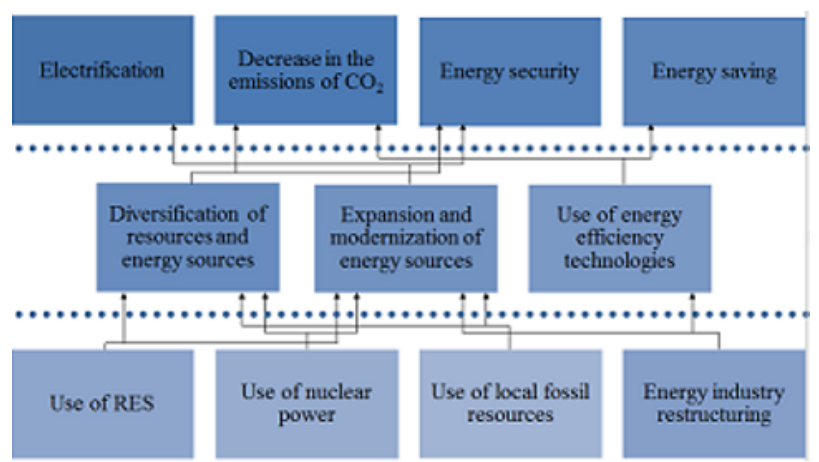

Figure 1. The vertically-integrated hierarchical structure of the sustainable energy development strategies

\section{Discriminant analysis of the countries' clusters}

By the results of the discriminant analysis 11 discriminant functions were received. Analyzing Wilks's Lambda coefficient and the own value of the discriminant functions it is possible to draw a conclusion that all the functions of the discriminant model are significant. The greatest difference in averages is observed in the first and second discriminant functions and consequently they describe the biggest number of the cases. The results of M. Box test (the importance is equal 0 that is below the threshold amount of 0.05 ) testify that not all the used variables have normal distribution. Besides, in the received model there is no multicollinearity problem, which is proved by the low correlation coefficients between predictors in integrated intra-group covariance and correlation matrixes. These facts allow drawing a conclusion on satisfactory reliability of the model and the possibility of the received results interpretation.

By the results of the discriminant analysis the countries were classified in 12 groups. The analysis of Wilks's Lambda coefficients and the statistical importance levels of predictors showed that the received groups differ, first of all, by the extent of use of such strategies as energy saving, modernization and expansion of energy sources, use of nuclear power, energy industry restructuring. Normalized coefficients of the canonical discriminant functions are presented in table 4 and 5 .

Table 4. Normalized coefficients of the canonical discriminant functions

\begin{tabular}{|l|r|r|r|r|r|}
\hline \multicolumn{1}{|c|}{$\begin{array}{l}\text { Independent } \\
\text { variables }\end{array}$} & \multicolumn{5}{|c|}{ Functions } \\
\cline { 2 - 7 } & 1 & 2 & 3 & 4 & 5 \\
\hline Electrification & -0.74 & -0.32 & 0.32 & 0.22 & -0.02 \\
\hline Energy saving & -0.10 & -0.14 & 0.44 & -0.09 & -0.46 \\
\hline $\begin{array}{l}\text { Expansion and } \\
\text { modernization } \\
\text { of energy } \\
\text { sources }\end{array}$ & -0.10 & 0.14 & 0.27 & 0.11 & 0.07 \\
\hline $\begin{array}{l}\text { Use of local } \\
\text { fossil } \\
\text { resources }\end{array}$ & -0.01 & 0.91 & -0.16 & 0.17 & -0.14 \\
\hline $\begin{array}{l}\text { Use of energy } \\
\text { efficiency } \\
\text { technologies }\end{array}$ & 0.11 & -0.24 & -0.49 & 0.19 & 0.06 \\
\hline $\begin{array}{l}\text { Decrease in } \\
\text { the emissions } \\
\text { of CO }\end{array}$ & 0.38 & -0.28 & 0.11 & 0.75 & -0.16 \\
\hline $\begin{array}{l}\text { Use of RES } \\
\text { Energy } \\
\text { security }\end{array}$ & 0.38 & 0.12 & 0.65 & -0.11 & -0.20 \\
\hline $\begin{array}{l}\text { Use of nuclear } \\
\text { power }\end{array}$ & -0.06 & 0.18 & 0.13 & 0.31 & 0.02 \\
\hline $\begin{array}{l}\text { Energy } \\
\text { industry } \\
\text { restructuring }\end{array}$ & -0.19 & 0.03 & 0.25 & 0.38 & 0.49 \\
\hline $\begin{array}{l}\text { Diversification } \\
\text { of resources } \\
\text { and energy } \\
\text { sources }\end{array}$ & 0.30 & -0.06 & 0.24 & -0.04 & 0.28 \\
\hline
\end{tabular}

Table 5. Normalized coefficients of the canonical discriminant functions

\begin{tabular}{|l|r|r|r|r|r|r|}
\hline \multirow{2}{*}{$\begin{array}{l}\text { Independent } \\
\text { variables }\end{array}$} & \multicolumn{7}{|c|}{ Functions } \\
\cline { 2 - 8 } & \multicolumn{1}{|l|}{6} & \multicolumn{1}{|l|}{8} & \multicolumn{1}{l|}{9} & \multicolumn{1}{l|}{10} & \multicolumn{1}{l|}{} \\
\hline Electrification & 0.09 & 0.35 & -0.03 & -0.09 & 0.50 & 0.07 \\
\hline Energy saving & -0.75 & 0.40 & 0.16 & 0.17 & -0.04 & 0.19 \\
\hline $\begin{array}{l}\text { Expansion and } \\
\text { modernization } \\
\text { of energy } \\
\text { sources }\end{array}$ & 0.49 & 0.38 & 0.06 & 0.58 & -0.43 & 0.00 \\
\hline
\end{tabular}




\begin{tabular}{|l|c|c|c|c|c|c|}
\hline $\begin{array}{l}\text { Use of local } \\
\text { fossil } \\
\text { resources }\end{array}$ & -0.02 & 0.12 & -0.20 & -0.13 & 0.22 & 0.15 \\
\hline $\begin{array}{l}\text { Use of energy } \\
\text { efficiency } \\
\text { technologies }\end{array}$ & 0.26 & 0.15 & 0.34 & 0.47 & 0.60 & 0.16 \\
\hline $\begin{array}{l}\text { Decrease in } \\
\text { the emissions } \\
\text { of CO }\end{array}$ & 0.23 & 0.13 & -0.39 & -0.26 & -0.17 & -0.06 \\
\hline Use of RES & 0.18 & -0.45 & -0.15 & 0.21 & 0.31 & 0.12 \\
\hline $\begin{array}{l}\text { Energy } \\
\text { security }\end{array}$ & -0.38 & 0.39 & -0.24 & 0.23 & 0.29 & -0.28 \\
\hline $\begin{array}{l}\text { Use of nuclear } \\
\text { power }\end{array}$ & 0.07 & -0.19 & 0.62 & -0.07 & 0.07 & -0.69 \\
\hline $\begin{array}{l}\text { Energy } \\
\text { industry } \\
\text { restructuring }\end{array}$ & -0.25 & -0.41 & 0.19 & 0.03 & -0.15 & 0.55 \\
\hline $\begin{array}{l}\text { Diversification } \\
\text { of resources } \\
\text { and energy } \\
\text { sources }\end{array}$ & 0.34 & 0.33 & 0.33 & -0.55 & 0.01 & 0.51 \\
\hline
\end{tabular}

The normalized coefficients of the canonical discriminant function serve for definition of a relative contribution of each variable to the value of the discriminant function, taking into account the influence of the other variables. Signs of coefficients are considered to be conditional. The more absolute value of the coefficient is, the more relative contribution of the given variable to the value of the discriminant function which divides the groups.

The own values of the canonical discriminant functions and the percentage of the dispersion explained with them are presented in table 6 .

Table 6. Own values of the canonical discriminant functions

\begin{tabular}{|c|c|c|c|c|}
\hline Function & Own value & $\begin{array}{l}\text { \% of the } \\
\text { dispersion } \\
\text { explained }\end{array}$ & \begin{tabular}{|c|} 
Cumulative \\
$\%$
\end{tabular} & $\begin{array}{l}\text { Canonical } \\
\text { correlation }\end{array}$ \\
\hline 1 & 0.891 & 46.5 & 46.5 & 0.686 \\
\hline 2 & 0.314 & 16.4 & 62.8 & 0.489 \\
\hline 3 & 0.272 & 14.2 & 77.0 & 0.462 \\
\hline 4 & 0.159 & 8.3 & 85.3 & 0.371 \\
\hline 5 & 0.107 & 5.6 & 90.9 & 0.311 \\
\hline 6 & 0.077 & 4.0 & 95.0 & 0.268 \\
\hline 7 & 0.053 & 2.7 & 97.7 & 0.224 \\
\hline 8 & 0.029 & 1.5 & 99.2 & 0.169 \\
\hline 9 & 0.008 & 0.4 & 99.7 & 0.090 \\
\hline 10 & 0.007 & 0.3 & 100.0 & 0.081 \\
\hline 11 & 0.000 & 0.0 & 100.0 & 0.010 \\
\hline
\end{tabular}

Normalized coefficients of the canonical discriminant function and the percentage of the dispersion explained with this function allow estimating what strategies are the most often used in some number of the countries.
Further the strategies which are the most often used by the certain countries are located in decreasing order on frequency. As appears from tables 3 and 4, 46.5 of \% of the countries under analysis give preference to such strategies as electrification, decrease in the emissions of $\mathrm{CO}_{2}$, use of RES (Hong Kong, Indonesia, etc.). For $16.4 \%$ of the countries the strategies of use of local fossil resources, electrification and decrease in the emissions of $\mathrm{CO}_{2}$ are typical (Bangladesh, Niger, etc.). 14.2\% of the countries apply widely such strategies as use of RES, energy efficiency technologies and energy saving (India, El Salvador, etc.). $8.3 \%$ of the countries under analysis are characterized by using the strategies of decrease in the emissions of $\mathrm{CO}_{2}$, energy industry restructuring and use of nuclear power (Malawi, Vietnam, etc.). Only $5.6 \%$ of the countries give preference to the strategies of energy security, energy industry restructuring and energy saving (Russian, Bosnia and Herzegovina, etc.). Such strategies as energy saving, modernization and expansion of energy sources, energy security are typical of $4.0 \%$ of the countries under analysis (Turkmenistan, the USA, etc.). $2.7 \%$ of the countries under analysis are focused on use of RES, energy industry restructuring and energy saving (Australia, Bulgaria, etc.). Only 1.5\% of the countries differ in realization of the strategies of use of nuclear power, decrease in the emissions of $\mathrm{CO}_{2}$, energy efficiency technologies (Hungary, the UK).

The coefficients of the classifying functions are presented in figure 3 . The coefficients of the classifying Fischer's function can be used directly for classification. For each group the separate set of coefficients is created, thus the case belongs to the group which has the greatest value of the discriminant function.

According to the coefficients of the classifying function of Fischer, all the strategies were ranged on the basis of a significance value for the countries under analysis. The strategy of use of RES (the maximum coefficient 26.221) took the first place, electrification (the maximum coefficient - 7.523) - the second, on the third - use of energy efficiency technologies (the maximum coefficient - 7.180) - the third , use of local fossil resources (the maximum coefficient - 5.528) - the fourth, decrease in the emissions of $\mathrm{CO}_{2}$ (the maximum coefficient - 5.445) - the fifth, energy security (the maximum coefficient - 4.619) - the sixth, energy saving (the maximum coefficient - 4.266) - the seventh, diversification of resources and energy sources (the maximum coefficient - 3.880) - the eighth, expansion and modernization of energy sources (the maximum coefficient - 3.597) - the ninth, energy industry restructuring (the maximum coefficient -3.388 ) - the tenth, use of nuclear power (the maximum coefficient 1.614) - the eleventh.

Besides, the broad application of the strategy of use of RES is caused also by world tendencies. On the whole, during 1990-2014 electricity generation from RES increased by 9.14 times (figure 2). 


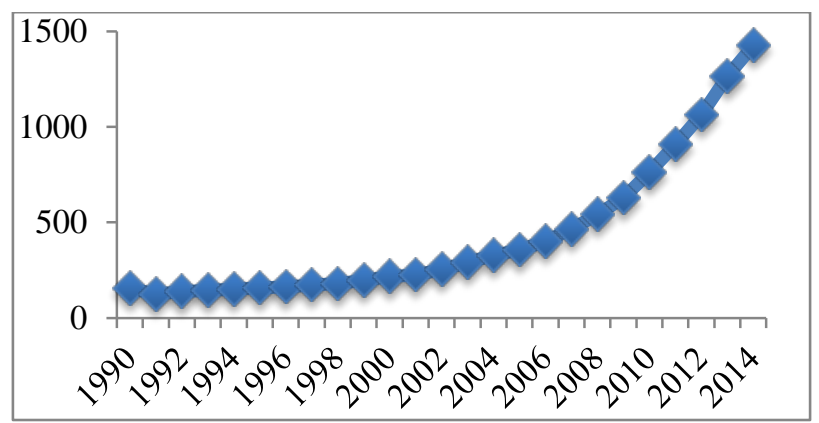

Figure 2. Electricity generation from RES for 19902014 in billions kWh.

The structure of the discriminant groups is presented in Figure 3.

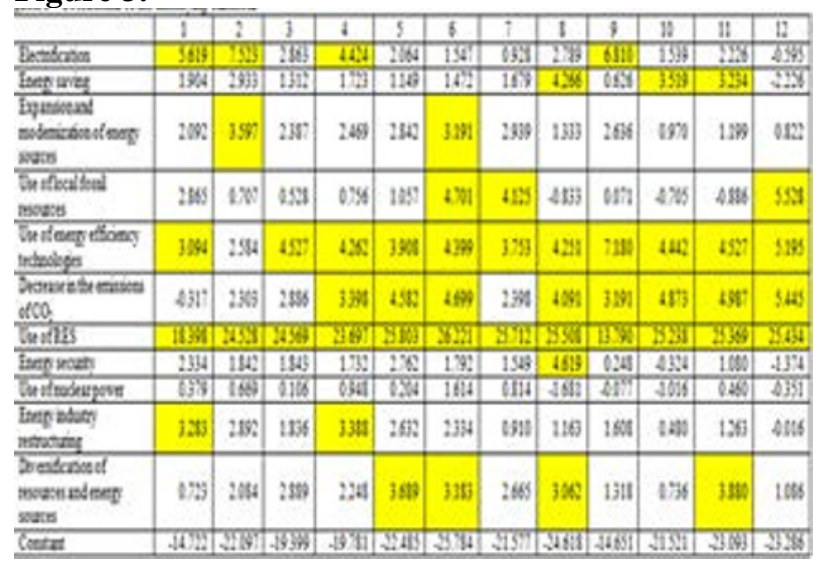

Figure 3. Coefficients of the classifying functions

Table 7. Description of the discriminant groups

\begin{tabular}{|c|c|c|c|c|c|c|c|c|c|c|}
\hline $\begin{array}{l}\text { 今े } \\
\text { 苞 }\end{array}$ & 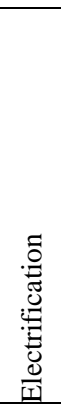 & 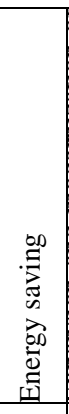 & 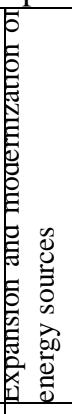 & 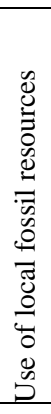 & 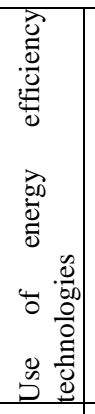 & 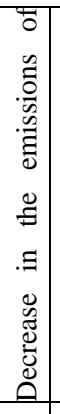 & 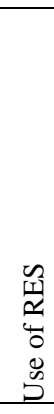 & 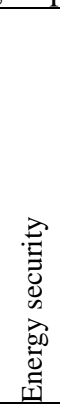 & 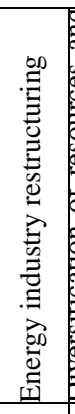 & 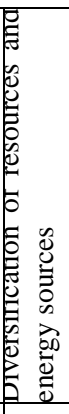 \\
\hline 1 & + & & & & + & & + & & + & \\
\hline 2 & + & & + & & & & + & & & \\
\hline 3 & & & & & + & & + & & & \\
\hline 4 & + & & & & + & + & + & & + & \\
\hline 5 & & & & & + & + & + & & & + \\
\hline 6 & & & + & + & + & + & + & & & + \\
\hline 7 & & & & + & + & & + & & & \\
\hline 8 & & + & & & + & + & + & + & & + \\
\hline 9 & + & & & & + & + & + & & & \\
\hline 10 & & + & & & + & + & + & & & \\
\hline
\end{tabular}

\begin{tabular}{|l|l|l|l|l|l|l|l|l|l|l|}
\hline 11 & & + & & & + & + & + & & & + \\
\hline 12 & & & & + & + & + & + & & & \\
\hline
\end{tabular}

Table 8. Description of the discriminant groups

\begin{tabular}{|c|c|}
\hline 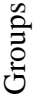 & Countries \\
\hline 1 & $\begin{array}{l}\text { Angola, Gabon, Namibia, Pakistan, Yemen, } \\
\text { Madagascar, Nepal, Niger, Uzbekistan }\end{array}$ \\
\hline 2 & $\begin{array}{l}\text { Ghana, Afghanistan, Benin, Burkina Faso, Cambodia, } \\
\text { Ethiopia, Haiti, Kenya, Malawi, Sudan, Togo, Uganda, } \\
\text { Butane, Burundi, El Salvador, Honduras, Mauritania, } \\
\text { Nicaragua, Papua New Guinea, Sri Lanka, Bolivia, } \\
\text { Côte d'Ivoire, Egypt, India, Iran, Philippines, } \\
\text { Mozambique }\end{array}$ \\
\hline 3 & $\begin{array}{l}\text { Armenia, Barbados, Brazil, Costa Rica, Dominica, } \\
\text { Georgia, Guatemala, Guyana, Iceland, Italy, Republic } \\
\text { of Korea, Latvia, Lebanon, Argentina, Chile, Bahrain }\end{array}$ \\
\hline 4 & $\begin{array}{l}\text { Eritrea, Zambia, Ecuador, Surinam, Uruguay, } \\
\text { Bangladesh, Botswana, Colombia, Nigeria, Peru, } \\
\text { Russia, Serbia, Vietnam, Hungary }\end{array}$ \\
\hline 5 & $\begin{array}{l}\text { Croatia, Finland, Gambia, Hong Kong, Japan, } \\
\text { Mauritius, Moldova, Morocco, Portugal, Turkey, } \\
\text { Montenegro, New Zealand, Germany, Iraq, Malaysia, } \\
\text { Slovenia, Thailand }\end{array}$ \\
\hline 6 & $\begin{array}{l}\text { Albania, Kyrgyz Republic, Bosnia and Herzegovina, } \\
\text { Indonesia, Mongolia, Romania, Bulgaria, Israel, } \\
\text { Australia, Canada, United Arab Emirates, USA, } \\
\text { Estonia, Kazakhstan }\end{array}$ \\
\hline 7 & $\begin{array}{l}\text { Cuba, Grenada, Jordan, the Republic of Slovakia, } \\
\text { Tajikistan, Czech Republic, Venezuela, Oman, Saudi } \\
\text { Arabia }\end{array}$ \\
\hline 8 & $\begin{array}{l}\text { Malta, Spain, Greece, Macedonia, Turkmenistan, } \\
\text { Ukraine, Luxembourg, Switzerland, Denmark }\end{array}$ \\
\hline 9 & $\begin{array}{l}\text { Senegal, Singapore, Algeria, Mexico, the Republic of } \\
\text { South Africa, the Democratic Republic of Congo, the } \\
\text { Republic of Congo, Zimbabwe }\end{array}$ \\
\hline 10 & $\begin{array}{l}\text { Cameroon, Austria, Dominican Republic, France, } \\
\text { Paraguay, Sweden, Azerbaijan, Syria, Kuwait, Trinidad } \\
\text { and Tobago, Norway }\end{array}$ \\
\hline 11 & $\begin{array}{l}\text { Belgium, Belarus, Ireland, Jamaica, Lithuania, China, } \\
\text { Poland, Tunisia, the United Kingdom of Great Britain } \\
\text { and Northern Ireland, Netherlands }\end{array}$ \\
\hline 12 & Cyprus, Burma, Brunei Darussalam, Tanzania, Qatar \\
\hline
\end{tabular}

Having compared the countries in clusters and discriminant groups (table 2 and 6) it is possible to draw a conclusion on incomplete coincidence of the results of the cluster and discriminant analysis. Thus, not all the countries possessing similar characteristics, use identical strategies within sustainable energy development.

For comparison of the predicted membership of the groups to clusters tables 9 and 10 were made.

Table 9. Predicted membership to the clusters in \%

\begin{tabular}{|l|l|l|l|l|l|l|}
\hline \multirow{2}{*}{ Cluster } & \multicolumn{6}{|c|}{ Predicted membership to the group } \\
\cline { 2 - 7 } & 1 & 2 & 3 & 4 & 5 & 6 \\
\hline 1 & 62.5 & 12.5 & 0 & 0 & 0 & 0 \\
\hline 2 & 7.1 & 78.6 & 0 & 14.3 & 0 & 0 \\
\hline 3 & 1.8 & 14.3 & 23.2 & 5.4 & 17.9 & 3.6 \\
\hline
\end{tabular}




\begin{tabular}{|l|l|l|l|l|l|l|}
\hline 4 & 5.7 & 14.3 & 5.7 & 22.9 & 5.7 & 11.4 \\
\hline 5 & 0 & 7.7 & 0 & 7.7 & 38.5 & 15.4 \\
\hline 6 & 0 & 0 & 0 & 0 & 0 & 100 \\
\hline 7 & 0 & 0 & 16.7 & 0 & 0 & 33.3 \\
\hline 8 & 0 & 0 & 0 & 0 & 0 & 0 \\
\hline 9 & 0 & 20 & 0 & 0 & 0 & 0 \\
\hline 10 & 0 & 0 & 0 & 0 & 0 & 0 \\
\hline 11 & 0 & 0 & 0 & 0 & 0 & 0 \\
\hline 12 & 0 & 0 & 0 & 0 & 0 & 0 \\
\hline
\end{tabular}

Table 10. Predicted membership to the clusters in \%

\begin{tabular}{|l|l|l|l|l|l|l|}
\hline \multirow{2}{*}{ Cluster } & \multicolumn{6}{|c|}{ Predicted membership to the group } \\
\cline { 2 - 7 } & 7 & 8 & 9 & 10 & 11 & 12 \\
\hline 1 & 0 & 0 & 12.5 & 12.5 & 0 & 0 \\
\hline 2 & 0 & 0 & 0 & 0 & 0 & 0 \\
\hline 3 & 8.9 & 3.6 & 1.8 & 8.9 & 8.9 & 1.8 \\
\hline 4 & 2.9 & 11.4 & 8.6 & 2.9 & 5.7 & 2.9 \\
\hline 5 & 7.7 & 0 & 0 & 7.7 & 15.4 & 0 \\
\hline 6 & 0 & 0 & 0 & 0 & 0 & 0 \\
\hline 7 & 33.3 & 0 & 0 & 0 & 0 & 16.7 \\
\hline 8 & 0 & 100 & 0 & 0 & 0 & 0 \\
\hline 9 & 0 & 0 & 60 & 0 & 0 & 20 \\
\hline 10 & 0 & 0 & 0 & 100 & 0 & 0 \\
\hline 11 & 0 & 33.3 & 0 & 33.3 & 33.3 & 0 \\
\hline 12 & 0 & 0 & 0 & 0 & 0 & 100 \\
\hline
\end{tabular}

As appears from tables 9 and 10, the countries belonging to $6,8,10$ and 12 clusters for $100 \%$ were correctly classified by means of the discriminant functions that is they adhere to standard strategies for their cluster. The smallest number of correctly classified countries belongs to the 4 th cluster $-22.86 \%$.

The results of the analysis of compliance of the sustainable energy development strategies planned for implementation till 2020 in the EEU countries and the ones recommended on the basis of the discriminant analysis are presented in table 11 .
Table 11. The strategies of sustainable energy development in the Eurasian Economic Union countries (a planned strategy according to the legal documents / a recommended strategy on the basis of discriminant analysis)

\begin{tabular}{|c|c|c|c|c|c|}
\hline & 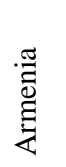 & 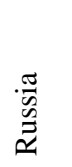 & 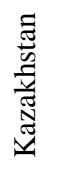 & 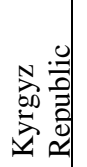 & 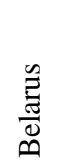 \\
\hline Electrification & & $-/+$ & & & \\
\hline Energy saving & & $+/-$ & $+/-$ & $+/-$ & $+/+$ \\
\hline $\begin{array}{l}\text { Expansion and } \\
\text { modernization of energy } \\
\text { sources }\end{array}$ & $+/-$ & & $+/+$ & $+/+$ & \\
\hline Use of local fossil resources & & & $+/+$ & $+/+$ & \\
\hline $\begin{array}{l}\text { Use of energy efficiency } \\
\text { technologies }\end{array}$ & $+/+$ & $+/+$ & $+/+$ & $+/+$ & $+/+$ \\
\hline $\begin{array}{l}\text { Decrease in the emissions of } \\
\mathrm{CO}_{2}\end{array}$ & & $+/+$ & $+/+$ & $+/+$ & $+/+$ \\
\hline Use of RES & $+/+$ & $+/+$ & $+/+$ & $+/+$ & $+/+$ \\
\hline Energy security & & $+/-$ & & $+/-$ & $+/-$ \\
\hline Use of nuclear power & $+/-$ & $+/-$ & $+/-$ & & $+/-$ \\
\hline $\begin{array}{l}\text { Energy industry } \\
\text { restructuring }\end{array}$ & & $+/+$ & & $+/-$ & \\
\hline $\begin{array}{l}\text { Diversification of resources } \\
\text { and energy sources }\end{array}$ & $+/-$ & & $+/+$ & $+/+$ & $+/+$ \\
\hline
\end{tabular}

The conducted research has shown that the different countries when forming their energy policy use various strategies of sustainable energy development, which doesn't always coincide with the recommended strategies on the basis of discriminant analysis.

D. Use of RES as the most typical strategy for sustainable energy development in the Eurasian Economic Union countries

For the analysis of the sustainable energy development strategies of the EEU countries the directions of the energy policy of these countries till 2020 have been studied (table 8).

According to the state program "Energy saving" for 2016-2020 [5], in Belarus the volume of fuel and energy resources saving during the specified period has to reach 5 million tons of coal equivalent and by 2021 the GDP energy intensity has to decrease not less than by 2 percent to the level of 2015, also this program provides increasing the share of RES in the gross energy consumption up to 6 percent. In Belarus energy security is traditionally paid considerable attention to. In 2015 the new edition of the Concept of energy security of the Republic of Belarus [6] was approved according to which the national interests of the country in the fuel and energy sphere are to achieve the level of energy security sufficient for neutralization of external dependence on receipt of energy carriers and also ensuring acceptable level of the fuel and energy balance diversification of the country by types of the consumed fuel and energy resources and by the countries - importers of the fuel and energy resources, at the same time the share of the dominating fuel type in the gross energy consumption 
by 2020 has to be lowered to 57\%. In the electricity sphere the Industry program of the electricity sector development for 2016-2020 [7] is the main document defining its strategy. This program assumes electricity capacities commissioning as one of the main results: on the NPP - $2388 \mathrm{MW}$, on SPA "Belenergo" sites - 340,3 MW, peak and reserve capacities - up to $800 \mathrm{MW}$, from ecological measures decrease in harmful substances and greenhouse gases emissions up to 10 percent will be provided due to replacement of fossil fuels with nuclear and RES and also increases in efficiency of fuel usage on the generating sources.

In Russia the main document defining the direction of energy development for a long-term period is the Energy strategy of Russia until 2030 [8]. This document provides increase in energy and environmental efficiency of the Russian economy and energy industry, including due to structural changes and activation of technological energy saving, completion of the transformations bringing adjacent sectors of economy to the new level of energy efficiency. As a practical result decrease in specific GDP energy intensity to 78 percent in comparison with 2000 is predicted by 2020, it should be noted that at the moment this indicator has reached 71.5 percent. As for the use of RES, by 2020 it is planned to bring a share of production and consumption of electricity generated on the basis of the use of RES technologies up to 4.5 percent from the total amount. Now in Russia the reform of the electricity industry has been already carried out, there is further liberalization of the electricity market and development of energy market infrastructure (market mechanisms, institutes of open trade in energy resources, infrastructure of their transport), the policy of step-by-step limitation of the fuel and energy sector impact on the environment and climate is implemented by decrease in emissions of pollutants, discharge of untreated waste water and also emission of greenhouse gases, reduction of energy production and consumption waste. One of the strategic reference points is energy security which is directed to improvement of the fuel and energy sector ability to reliably provide economically reasonable domestic demand for energy carriers of the corresponding quality and at acceptable cost; increase in the ability of the consumer sector of the economy to effectively use energy resources, preventing the society from irrational costs of the own power supply; increase in resistance of the energy sector to external and internal economic, technogenic and natural threats of reliable fuel and energy supply and also its ability to minimize the damage caused by manifestation of various destabilizing factors. The guarantee of the direct state support of nuclear power development is also declared in the strategy.

The strategic development plan for the Republic of Kazakhstan till 2020 [9] includes the following purposes in the energy sphere: reconstruction and modernization of the existing generating energy capacities and distributive electricity networks; the energy production from the own sources satisfying the requirements of economy will make 100 percent; the share of the use of alternative energy sources in the gross energy consumption will make more than 3 percent; construction of the NPP and putting it into operation, creation of a vertically integrated company with a nuclear fuel cycle. In the sphere of environmental protection and transition to "green economy" it is planned to decrease GDP energy intensity from the level of 2008 by 25 percent and emissions of carbon dioxide in the electricity industry to the level of 2012.

The energy policy of Kyrgyz Republic is defined by the Strategy of the fuel and energy sector development till 2025 [10]. Energy and ecological security are strategic reference points of the long-term energy policy. The purpose of the energy security policy is gradual improvement of its following main characteristics: the ability of the fuel and energy sector to satisfy economically reasonable internal and external demand with energy carriers of the corresponding quality and at an acceptable cost. The energy policy of Kyrgyz Republic is also focused on accounting of requirements of ecological safety, environmental protection and the use of renewable energy sources and prevention of irrational use of energy resources. Control of energy resources consumption growth rates will be limited to the level of $0.6-0.8$ from the GDP growth rates by 2025. The main goals of the electricity industry development until 2025 are completion of the electricity system reform as a full element of the market economy according to the new provisions of the energy policy, with approval of necessary regulatory legal acts directed to regulation of the processes happening in the sector, creation of market mechanisms of interstate cooperation; modernization and accumulation of the electricity system production potential and increase in its efficiency on the basis of the use of new technologies, introduction of automated control systems and optimum regulation of production loads; creation of the generating capacities and the transmission and distribution electricity lines on the basis of the hydropower resources and the country's coal fields usage focused, mainly, on the electricity export and supply of the large energy intensive industries promoting increase in the sector efficiency and the sustainable development of the economy of Kyrgyz Republic.

In Armenia the use of energy efficiency technologies, first of all, is provided on small hydroelectric power stations. It is expected that with adoption of new technical regulations the situation with small hydroelectric power stations in Armenia will improve, and in the long term it will possible to ensure the sustainable development of small hydropower. The energy policy of Armenia [11] is directed to diversification of the used energy sources. So, within next years it is planned to increase considerably a share of the renewable energy in the energy balance by means of the construction of solar, wind and geothermal stations (for example, it is planned to build heliostations of 40-50 MW which will be ready for operation by 2020), by 2027 the new nuclear energy unit of $600 \mathrm{MW}$ will be put into operation. Its construction is planned to begin in 2018-2019. Also expansion and modernization of the existing energy sources is provided. For example, by May, 2019 it is planned to construct the second 
energy unit of Yerevan power plant of $250 \mathrm{MW}$ with the combined steam-gas cycle.

The carried-out analysis of the energy policy of the EEU countries has shown that in the power industry it is typical for all these countries to apply "use of RES" strategy.

Figure 4 presents the electricity production balance in Belarus in 2000-2015 and the structure of electricity production from RES in 2015.

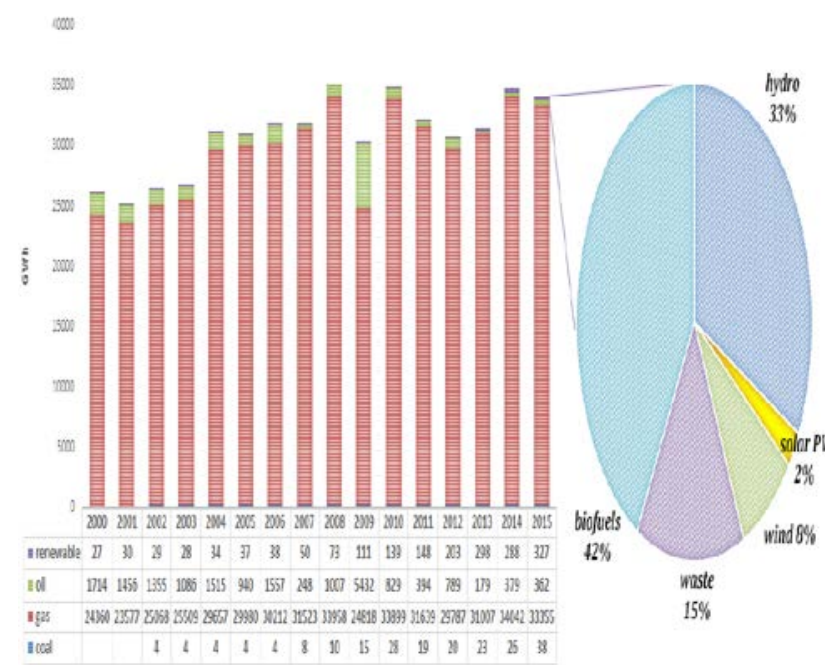

Figure 4. The electricity production balance in Belarus in 2000-2015, GWh and the structure of electricity production from RES in 2015, \%

In 2000 in Belarus $0.1 \%$ of electricity was generated from renewable energy sources (hydro power) and 99.90\% - from fossil fuels (oil and gas); in 2015 0.96\% of electricity was produced from renewable energy sources (hydro power, wind, biofuels, solar PV and waste) and 99.04\% - from fossil fuels (gas, oil and coal). Figure 5 presents the electricity production balance in Armenia in 2000-2015 and the structure of electricity production from RES in 2015.

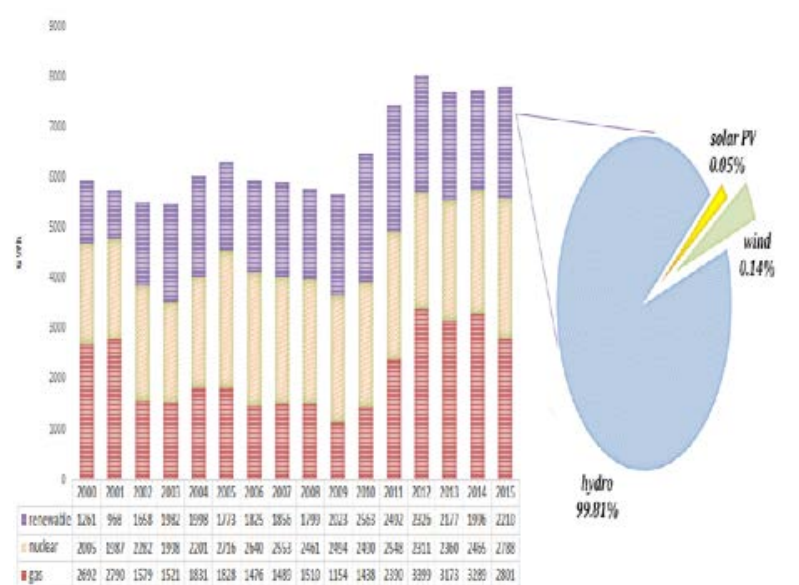

Figure 5. The electricity production balance in Armenia in 2000-2015, GWh and the structure of electricity production from RES in 2015, \%
In Armenia in $200021.16 \%$ of electricity was generated from renewable energy sources (hydro power), 33.65\% from nuclear energy and $45.18 \%$ - from fossil fuels (natural gas); in $201528.34 \%$ of electricity was produced from renewable energy sources (hydro power, solar PV and wind), 35.75\% - from nuclear energy and $35.91 \%$ - from fossil fuels (gas).

Figure 6 presents the electricity production balance in Kazakhstan in 2000-2015 and the structure of electricity production from RES in 2015.

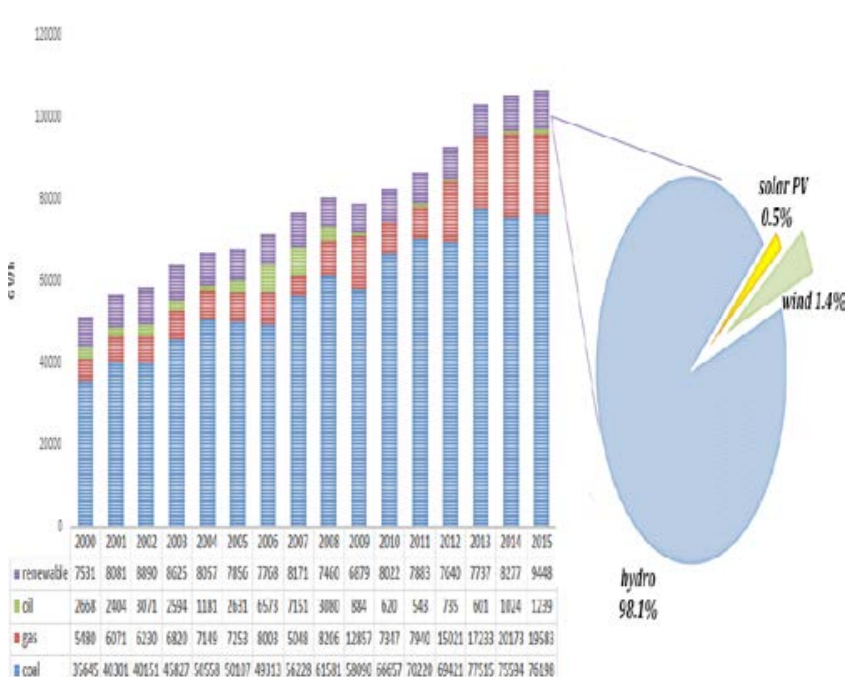

Figure 6. The electricity production balance in Kazakhstan in 2000-2015, GWh and the structure of electricity production from RES in 2015, \%

In Kazakhstan in $200014.67 \%$ of electricity was generated using renewable energy sources (hydro power) and $85.33 \%$ - using fossil fuels (coal, oil and gas); in $20158.87 \%$ of electricity was produced from renewable energy sources (hydro power, wind and solar PV) and $91.13 \%$ - from fossil fuels (coal, oil and gas).

Figure 7 presents the electricity production balance in Kyrgyz Republic in 2000-2015 and the structure of electricity production from RES in 2015. 


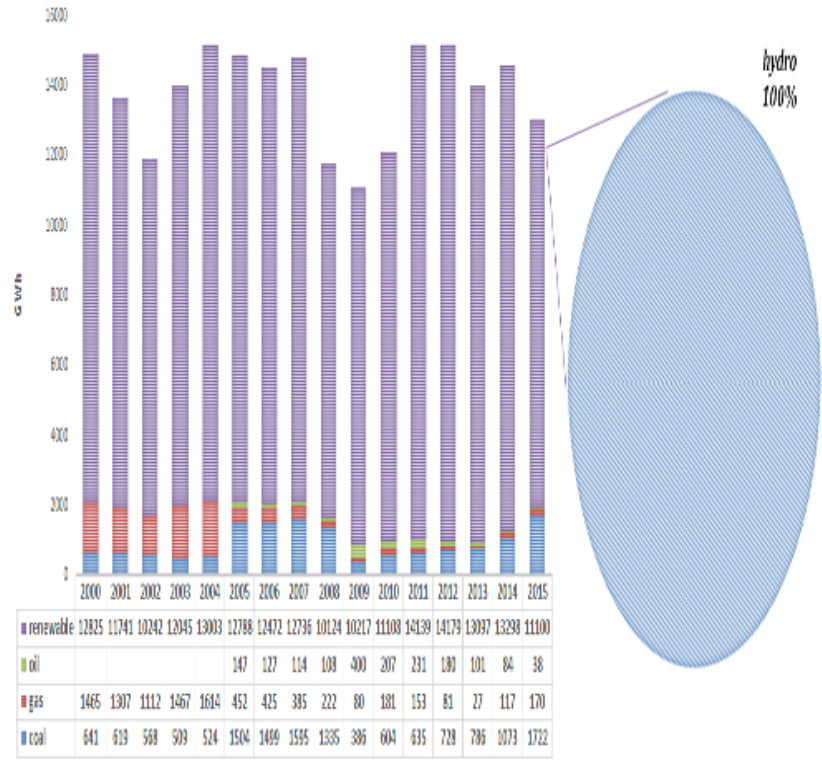

Figure 7. The electricity production balance in Kyrgyz Republic in 2000-2015, GWh and the structure of electricity production from RES in 2015, \%

In Kyrgyz Republic in 2000 85.90\% of electricity was generated from hydro power and $14.10 \%$ - from coal and natural gas; in 2015 85.19\% of electricity was produced from hydro power and $14.81 \%$ from coal, natural gas and oil.

Figure 8 presents the electricity production balance in Russia in 2000-2015 and the structure of electricity production from RES in 2015.

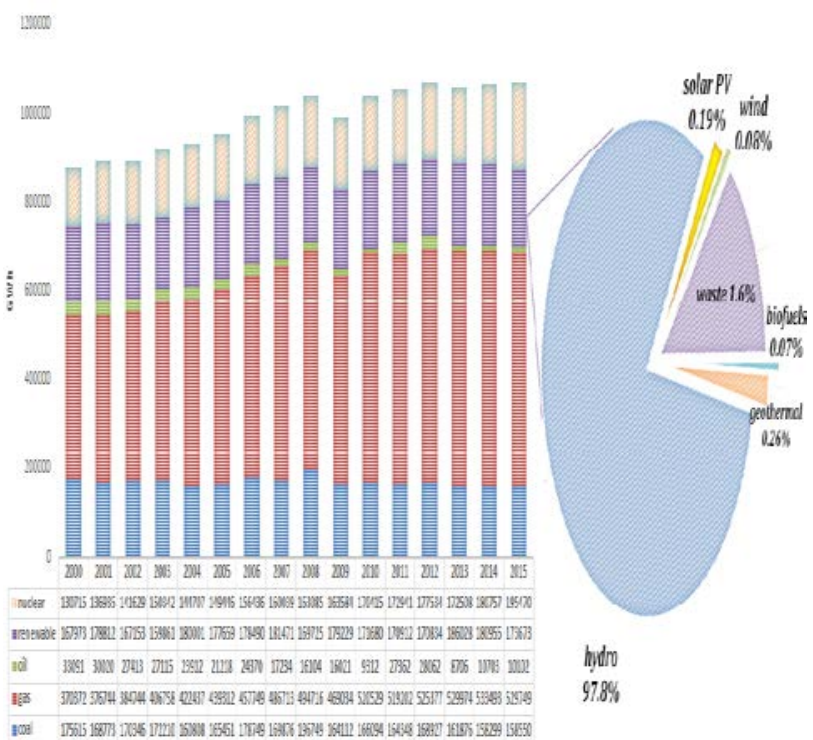

Figure 8. The electricity production balance in Russia in 2000-2015, GWh and the structure of electricity production from RES in 2015, \%

In Russia in 2000 19.14\% of electricity was generated from renewable energy sources (waste, hydro power, geothermal energy, wind and biofuels), $14.89 \%$ - from nuclear energy and $65.97 \%$ - from fossil fuels (coal, oil and natural gas); in 2015 16.27\% of electricity was produced from renewable energy sources (waste, hydro power, geothermal energy, wind, solar PV), 18.31\% from nuclear energy and $65.42 \%$ - from fossil fuels (coal, oil and natural gas).

Having studied the experience of RES usage in the EEU countries in 2000-2015 it is possible to draw a conclusion that in the majority of the countries of this association the use of RES is insignificant and also there is no deep diversification of different types of RES.

\section{Conclusions}

Thus, as a result of the carried-out discriminant analysis it is possible to draw a conclusion that only $38.3 \%$ of the countries under analysis use the strategies in the field of energy typical of the cluster, it means the strategies corresponding to the level of economic development, the amount of harmful emissions in the atmosphere, the level of electrification of the country and the stock level of energy resources.

There are several reasons of discrepancy between cluster membership and the used strategies. First, some countries are guided by the world tendencies in energy without paying attention to their own peculiarities. It often leads to impossibility of implementation of the programs approved at the level of the state in the field of energy policy. Second, part of the countries uses the strategies of leaders, which doesn't allow them to pay the necessary attention to the solution of the paramount tasks. Third, membership in some unions or associations make the country fulfill certain requirements for energy policy of these associations, which is not always economically reasonable because of the heterogeneity of these countries (for example, the EU countries). Fourthly, there is no integrated approach to formation of energy policy of the countries that affects impossibility to estimate the aggregate effect from realization of the actions.

Nowadays all the EEU countries consider the strategy of use of RES as a priority.

Barriers for RES usage in Belarus:

- $\quad$ excess of the generating capacities in the country with the introduction of the second energy unit of the NPP in 2020;

- establishment of quotas for RES capacities introduction (for 2020 the quotas are the following: 2.72MW for biogas energy, 2.50 MW for wind generators, 5.025 MW for solar energy, 33.00MW for hydro power, 13.00MW for biomass energy)

Incentives for RES usage in Belarus:

- feed-in tariffs for supplying the electricity from RES to the grid for the first 10 years after putting the generating unit into operation for the units within the quotas;

- large biomass resources

- $\quad$ adoption of the subprogram "Development of local fuel and energy resources usage, including renewable ones” for 2016-2020 within the program "Energy saving"

Barriers for RES usage in Armenia:

- the low technical level of the small hydropower stations infrastructure 
- $\quad$ negative impact of the small hydropower stations on the environment through inappropriate institutional, legal and technical regulation

Incentives for RES usage in Armenia:

- $\quad$ tax benefits for the companies working in the RES industry

- the guarantee of the fixed tariffs for 20 years for the produced energy supply

- an enormous potential of the RES usage (for example, the potential of hydro power in Armenia is estimated to be 21.8 billion $\mathrm{kWh}$ per year, the potential of wind power resources is 1.26 billion kWh per year)

- $\quad$ interest from the investors (for example, in 2015 the investment program of 58 million dollars to develop RES started in Armenia at the support of the Climate Investments Fund, the Ministry of energy infrastructures and natural resources, the World Bank, the Asian Development Bank) [11]

Barriers for RES usage in Kazakhstan

- lack of well-developed legal background for RES support

- $\quad$ high inflation rate which makes foreign investments payback period longer and lowers the interest from potential investors [12]

Incentives for RES usage in Kazakhstan:

- RE Auctions mechanism to attract investment to the RES industry will come in force in May, 2018

- support by the international institutions (for example, in 2017 the European Bank for Reconstruction and Development invested 50 million dollars in solar energy in Kazakhstan)

- the long-term strategy of the government to reach $50 \%$ of RES in the energy balance by 2050

- the potential of RES is estimated to be close to 1 trillion kWh per year

Barriers for RES usage in Kyrgyz Republic:

- $\quad$ weak legal background to support RES usage

- $\quad$ lack of experts in the field

- weak mechanisms of financial support, low inclusion of foreign and local investment

- low information awareness about the RES advantages [13]

- $\quad$ underdevelopment of RES, except for hydro power

Incentives for RES usage in Kyrgyz Republic:

- gradual formation of the local market of RES equipment (such companies as "ESS" (heat pumps, solar units, etc.), “Gidroponika” (small hydro power stations), etc.)

- $\quad$ information campaigns to promote RES among the population

- good climate and geographical position for RES (for example, 260 sunny days during the year as a potential for solar energy development)

Barriers for RES usage in Russia:

- $\quad$ underdevelopment of RES, except for hydro power (the total RES capacity is $53.5 \mathrm{GW}$, out of which 51.5 GW is for hydro power) [14]

- low competitive power in comparison with the traditional power supply system due to large reserves of fossil fuels and their relatively cheap price
Incentives for RES usage in Russia:

- high interest from the investors including foreign ones (by 2022 2.3 GW of RES capacities will be put into operation)

- research and development projects in energy storage technologies

- there are about 100000 of isolated areas where the traditional power supply system is hardly possible or too expensive

- $\quad$ legal support of RES development

Some recommendations:

1 ) it is necessary to develop specific program documents concerning the strategies of energy policy and means of their realization in the long-term period;

2) it is recommended to use accurate hierarchies of the strategies while creating these documents;

3 ) it is necessary to adapt the strategies of energy policy for the operating conditions of the countries.

4) such countries of the Eurasian Economic Union as Belarus and Kazakhstan need serious intensification in terms of RES usage taking into consideration barriers and incentives.

\section{References}

1. The World Bank [Online]. Available: https://data.worldbank.org/.

2. UN, Department of Economic and Social Affairs [Online].

Available: https://unstats.un.org/unsd/energy/balance/.

3. International Energy Agency [Online]. Available: https://www.iea.org/statistics/relateddatabases/energystat isticsofoecdcountries/.

4. T. Zoryna, "Sustainable energy development: countries and strategies”, Sustainable Energy Policy and Strategies for Europe : 14th International Association for Energy Economics European Conf., Rome, 28-31 Oct. 2014, pp. 278-281.

5. The state program "Energy saving" for 2016-2020, 28.03.2016, № 248.

6. The Concept of energy security of the Republic of Belarus, 23.12.2015, № 1084

7. The Industry program of the electricity sector development for 2016-2020, 31.03.2016, № 8 .

8. The Energy strategy of Russia until 2030, 13.11.2009, № 1715-p [Online]. Available: https://minenergo.gov.ru/node/1026.

9. The strategic development plan for the Republic of Kazakhstan till 2020 [Online]. Available: http://www.akorda.kz/ru/official_documents/strategies_a nd_programs.

10. The Strategy of the fuel and energy sector development till 2025, 13.02.2008, № 47.

11. Ministry of Energy Infrastructures and Natural Resources of the Republic of Armenia [Online]. Available: http://www.minenergy.am/en. 
12. A. Sydykova, "Problems of RES development in Kazakhstan”, Energy and Electric Equipment [Online]. Available: http://kzenergy.kz/2017/11/13/problemyrazvitiya-vie-v-kazahstane/.

13. A. Postnov, "The main aspects of RES development in Kyrgyz Republic”, Akmena [Online]. Available: https://carnegieendowment.org/files/Presentation_\%20Postnov\%20Rus.pdf.

14. V. Osmakov, "Watts and technologies-2: barriers and prospects of RES development in Russia", Forbes [Online]. Available:

http://www.forbes.ru/tehnologii/350445-vatty-i-

tehnologii-2-barery-i-perspektivy-razvitiya-vie-v-rossii. 